\title{
Impact of Human Colonization on the Landscape: A View from the Western Pacific ${ }^{1}$
}

\author{
Glenn R. Summerhayes, ${ }^{2,4}$ Matthew Leavesley, ${ }^{2}$ and Andy Fairbairn ${ }^{3}$
}

\begin{abstract}
In this paper we review and assess the impact of colonizing peoples on their landscape by focusing on two very different colonizing processes within the western Pacific. The first is the initial human colonization of New Guinea $45,000-40,000$ years ago by hunter-foraging populations; the second is the colonization of smaller offshore islands of the Bismarck Archipelago, some 3,300 years ago, by peoples argued to have practiced agriculture: two different colonizing processes by two different groups of peoples with two different social structures practicing two very different subsistence strategies. The impact of these two colonization processes on the environment is compared and contrasted, and commonalities identified for the archaeological and vegetation record.
\end{abstract}

WhereVER AND WHENEVER members of our species colonized areas of the planet for the first time, they have had an impact on the environment, and as archaeologists we are in a unique position to measure and assess these impacts. The most immediate effects were felt as a result of subsistence strategies, whether the nature of colonization was by hunter-gatherers between 45,000 and 40,000 years ago or by agriculturalists at 3,300 years ago. Yet the question addressed in this paper is whether such impacts on the environment, or "fingerprints," can be actually measured. Are the data available that will allow us to assess these impacts? In the cases where we argue that the data are available, are we measuring colonization impacts or are we recording the impacts of later adaptations? It should be noted that colonization is a process and not an event! We outline the nature of these

\footnotetext{
${ }^{1}$ Manuscript accepted 10 January 2009.

2 Anthropology, Gender and Sociology, University of Otago, P.O. Box 56, Dunedin, Otago, New Zealand.

${ }^{3}$ School of Social Science, University of Queensland, St Lucia, Queensland 4072, Australia.

${ }^{4}$ Corresponding author (e-mail: glenn.summerhayes@stonebow.otago.ac.nz).
}

Pacific Science (2009), vol. 63, no. 4:725-745

(C) 2009 by University of Hawai'i Press

All rights reserved changes by focusing first on the Pleistocene colonization of New Guinea and second on the colonization of the western Pacific by Lapita agriculturalists.

\section{PLEISTOCENE COLONIZATION LANDSCAPES}

It has been argued that the early colonists to Sahul focused on coastal resources to which they had adapted (Allen 2000). Jim Allen hypothesises that these peoples were "small groups of mobile, broad spectrum foragers" who exploited both maritime and terrestrial resources (Allen et al. 1989:558-559, Allen and Gosden 1996:187). Yet modeling the nature of these early colonizers is all the more difficult because we are assessing a period of time described so aptly by Chris Gosden (1993:133) as a world without ethnographic parallel. These colonists entered an unfamiliar environment that supported a diverse Gondwana-derived flora and fauna. At least 40,000 years of vegetation clearance, burning, hunting, and, more recently, agriculture has done much to alter this environment. Yet, can we measure the impact of the first settlers on this landmass?

The answer to this question in part depends on the nature of those early colonizers and what they left behind in the archaeological record. There are few sites dating to the early colonization of New Guinea, with fewer still allowing a glimpse at the nature of their 


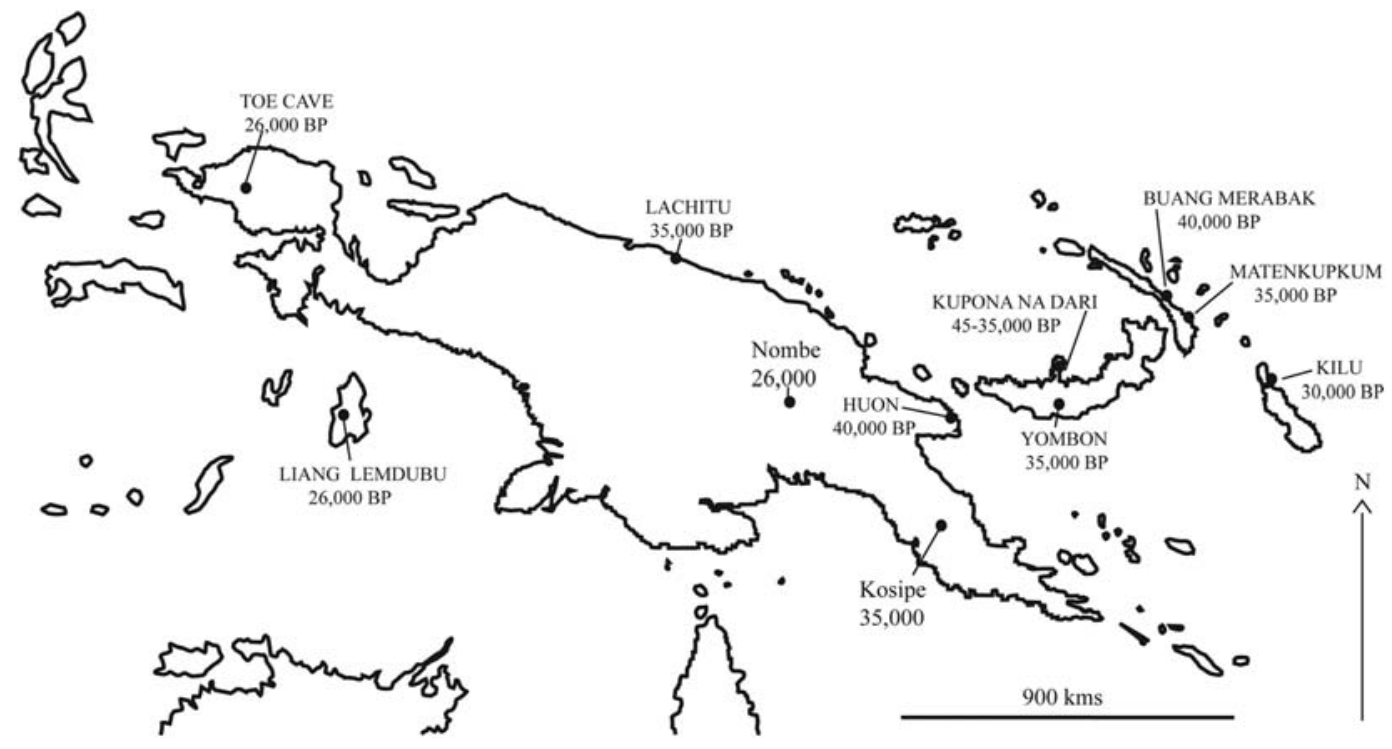

Figure 1. First footsteps in New Guinea: sites dated to ca. 40,000-20,000 B.P.

occupation (Figure 1). Only 10 sites (11 if you include one located in the Aru Islands) have evidence with occupation dating to between 40,000 and 20,000 B.P. (uncalibrated radiocarbon years) (see Table 1). From these 10 sites, only seven show occupation at or older than 35,000 years: Lachitu, Huon, and Kosipe from mainland New Guinea; Yombon and Kupona $\mathrm{Na}$ dari from New Britain; and Buang Merabak and Matenkupkum from
New Ireland. The rapid spread of the early colonizers is seen in the age distribution of these early sites (see earlier), and it is from these sites that any impact colonization and adaptation had on the environment should be measured. A brief description of each of these seven sites follows, outlining the data available. A full description of these sites is important because we argue that a lack of data from the majority of them makes an

TABLE 1

Pleistocene Sites: 40,000-20,000 B.P.

\begin{tabular}{lll}
\hline \hline \multicolumn{1}{c}{ Site Name } & Age (B.P.) & \multicolumn{1}{c}{ References } \\
\hline 1. Lachitu & 35,000 & Gorecki et al. (1991), Chappell (2000: table 1) \\
2. Huon & 40,000 & Groube et al. (1986) \\
3. Kosipe & 35,000 & Fairbairn et al. (2006) \\
4. Nombe & 26,000 & Gillieson and Mountain (1983), Mountain (1991) \\
5. Yombon & 35,000 & Pavlides and Gosden (1994) \\
6. Kupona Na dari & $45,000-35,000$ & Torrence et al. (2004) \\
7. Buang Merabak & 40,000 & Leavesley et al. (2002), Leavesley and Chappell (2004) \\
8. Matenkupkum & 35,000 & Summerhayes and Allen (1993) \\
9. Kilu & 29,000 & Wickler and Spriggs (1988) \\
10. Toe Cave & 26,000 & Pasveer (2004) \\
11. Liang Lemdubu & 26,000 & Veth et al. (1998) \\
\hline
\end{tabular}


assessment of colonization impacts difficult to measure.

LACHITU. Lachitu rock shelter (Papua New Guinea [PNG] National Museum site code RIQ) is located on the slopes of the Oenake Range, in the Musu-Fichin area on the north coast of New Guinea in the province of West Sepik. The Musu-Fichin area is just over $10 \mathrm{~km}$ east of the international border with the Indonesian province of Papua and $18 \mathrm{~km}$ west of the provincial capital, Vanimo. The site was located and excavated by Paul Gorecki over a number of field seasons (1990 and 1991). Unfortunately, the results of the second season excavation, which has evidence for human occupation at 35,000 B.P., are unpublished. Thus Lachitu cannot contribute to identifying the impact that colonization had on this region or immediate adaptations, other than noting that early occupation exists (see Gorecki et al. [1991] for a preliminary report).

HUON PENINSUla: вовONGara. The Huon Peninsula, jutting out from the east coast of New Guinea, has an imposing coastline, made up of raised terraces climbing hundreds of meters out of the sea. It was on one of these raised terraces that remnants of peoples who occupied this coastline 40,000 years ago were found. In 1980 Les Groube led a team of students on a field trip to the Huon Peninsula (Groube et al. 1986). Alerted to the antiquity of the peninsula by geomorphologist Professor John Chappell (Australian National University), Groube and his students found over 100 surface finds of waisted axes in an area called Fortification point, below Bobongara Hill (PNG National Museum site code KIJ). These tools were found in terraces 80 to $200 \mathrm{~m}$ above sea level. A number of subsequent field trips undertaken by Groube and his students from the University of Papua New Guinea has taken place (see Groube et al. 1986).

The location and dating of the raised terraces is important. First, these were once coastal sites. Finding comparable 40,000year-old coastal occupation sites is difficult because many would have been destroyed by rising sea levels. Second, attention focused on terraces because John Chappell had already dated a nearby raised reef using ${ }^{230} \mathrm{Th} /{ }^{234} \mathrm{U}$ methods to 48,000 years.

Groube and his team conducted archaeological excavations along and into the bank of a stream (Jo's Creek) that cut perpendicularly into the terraces, exposing a number of stratigraphic units. Artifacts including waisted axes were found in situ within a tephra that was dated by thermoluminescence dating to around 40,000 years. The underlying coral is dated to between 50,000 to 60,000 years old. The waisted stone tools are large and unifacial (flaked on one surface). They average in weight at just under $2 \mathrm{~kg}$ (with the largest found over $2.6 \mathrm{~kg}$ ) and range between 10 to $22 \mathrm{~cm}$ in length.

It is the waisted axes that are useful in modeling early colonists' impact on the environment. Waisted axes have been found in other archaeological sites in New Guinea (see Kosipe following) and Australia; however, these finds from the Huon are the earliest. Groube (1986, 1989) speculated about their use, noting that the nature of the raw material precluded obtaining a sharp edge, thus they were probably not used as a sharp chopping tool. The waist, however, does suggest hafting onto a wooden handle. Groube (1989:296-297) argued that they were probably used for forest clearance such as ring barking, root clearance, or even in obtaining foods such as thinning Pandanus strands to enable fruit ripening or the processing of sago.

коsipe. The Kosipe Valley contains some of the oldest remains left by people some 35,000 years ago. Located in the Owen Stanley Mountain Range, it sits 2,000 $\mathrm{m}$ above sea level, thus providing a unique glimpse into peoples' adaptability during the late Pleistocene.

The archaeological site (PNG National Museum site code AER) is located in the grounds of the Kosipe Sacre Coeur Mission, on a ridge overlooking the Kosipe Valley. Evidence of prehistoric occupation was brought to light in the 1960s by the Catholic Fathers of the mission, who found waisted stone axes while digging church foundations. Peter White subsequently excavated Kosipe over two seasons in the mid- to late 1960s. 
Kosipe is basically a hillside surface scatter of stone tools overlying a well-stratified deposit of archaeological materials. The tools in association with carbon are sandwiched between volcanic tephras from Mt. Lamington, located $140 \mathrm{~km}$ away. White excavated over $47 \mathrm{~m}^{2}$ over two seasons. Deposits down to between $80-100 \mathrm{~cm}$ were excavated.

White et al. (1970) radiocarbon dated charcoal found with the earliest occupation to 26,000 B.P., making this, at the time, the oldest evidence of people in New Guinea. White argued that people may have traveled to this high-altitude area in search of mountain Pandanus. Also waisted stone tools were found, similar to those found at the late Pleistocene sites of the Huon Peninsula, which could have been used in forest clearance or Pandanus harvesting.

The Kosipe Valley was revisited by Geoff Hope, a paleobotanist, in 1970 (Hope 1982). He took a number of pollen cores from the Kosipe valley floor and demonstrated forest clearance at some 35,000 B.P., with an increase in the use of fire to clear the vegetation. Hope returned again in 2005, this time with Professor Glenn Summerhayes, an archaeologist from the University of Otago. Summerhayes and his team reexcavated Kosipe and extended human occupation in that region to 35,000 B.P. (see Fairbairn et al. 2006). Of importance was the identification of Pandanus seeds using a scanning electron microscope, in the levels dated to 30,000 B.P. radiocarbon years. These were found in the same levels as the waisted stone tools (see Figure 2).

Kosipe is important because it provides important evidence to show that early modern humans not only adapted their behavior to new environments but also used and deliberately managed the landscape by fire. This is some of the earliest evidence in the world of modern peoples changing their landscapes by fire.

уомвоn. Yombon (PNG National $\mathrm{Mu}-$ seum site code FGT and FIF) has evidence of early occupation dating from ca. 35,000 B.P. Yombon is an open site ca. $500 \mathrm{~m}$ above sea level located in the rain forest jungles in the rugged karst interior of New Britain, about $35 \mathrm{~km}$ from the south coast district headquarters of Kandrian. Rainfall in the interior of New Britain is over $6,000 \mathrm{~mm}$ per annum. The area's importance was first identified in the 1970s by Jim Specht from the Australian Museum, who had camped there on his way to excavate Misisil Cave. In 1991 and 1993 Christina Pavlides returned to Yombon as part of her Ph.D. research and excavated 10 trenches, five in nearby hamlets (site FIF). The excavations, reaching a depth of $2 \mathrm{~m}$, revealed a series of tephras, or ashes, originating from volcanoes over $95 \mathrm{~km}$ away on the north coast of New Britain, separated by brown sticky clays containing stone tools made from chert. In such volcanic clays little organics survived such as bone, although a few pieces of carbon were found that provide a tight sequence of occupation going back 35,000 B.P. (Pavlides and Gosden 1994, Pavlides 1993, 1999, 2004, 2006).

The presence of early occupation and the exploitation of chert sources in the tropical rain forests of the late Pleistocene demonstrates the adaptability of humans in the colonization of New Britain. Such occupation also contradicts popular models that argue that those early inhabitants were opportunists living on the coast and that occupation in the rain forests occurred only in association with fishing or agriculture, the latter occurring during the Holocene.

KUPONA NA DARI. Kupona Na dari (PNG National Museum site code FABM) was excavated by Robin Torrence in the late 1990s and early 2000s, as part of her long-term research in western New Britain. It is an open site located on a small hill just over half a kilometer from the coast near the eastern base of the Willaumez Peninsula. The site is basically a series of cultural levels separated by successive volcanic tephras (Torrence et al. 2004). The oldest radiocarbon (AMS) dates were only Holocene in age. Luminescence dating provided age estimates of 38,00039,000 years ago (Torrence et al. 2004:116). Fission Track dating was also undertaken on obsidian. Because of the nature of the volcanic deposit, no organics were preserved, restricting the modeling of the nature of social and economic structures to stone tools. 

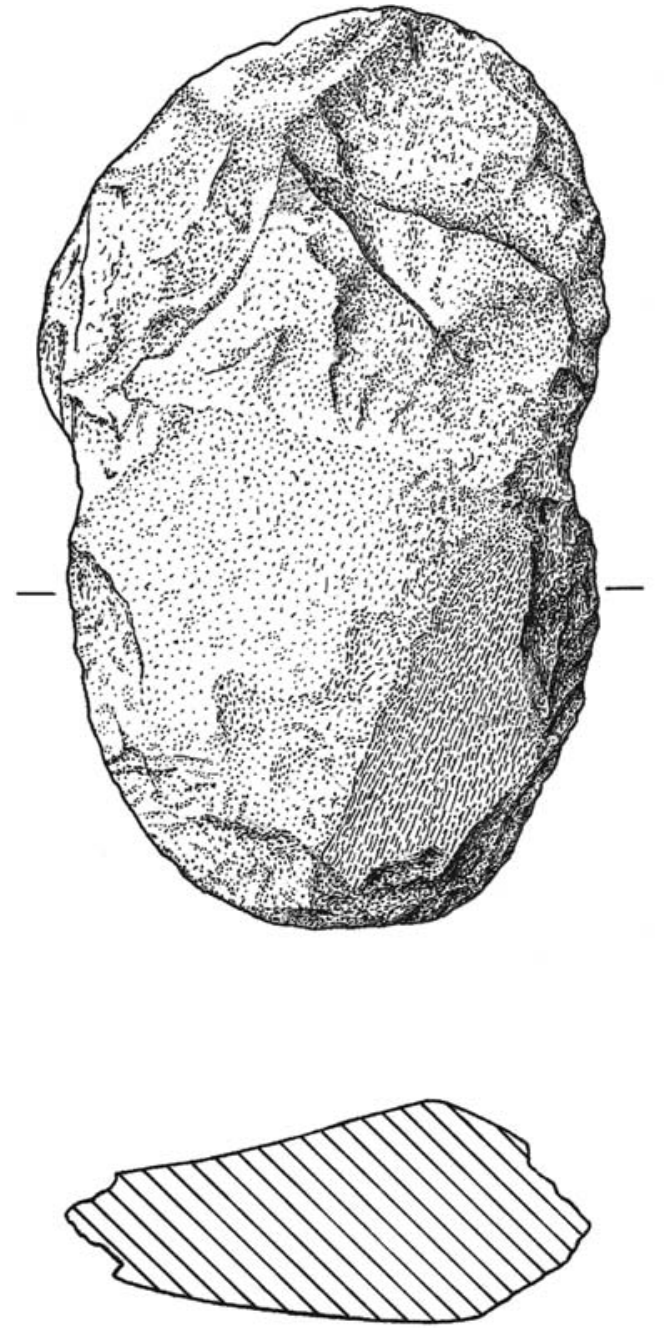

Figure 2. Waisted axe from Kosipe.

At its earliest levels both Mopir and Gulu obsidian were found, with Kutau making an appearance toward the terminal Pleistocene/ early Holocene boundary (Torrence et al. 2004:119). Torrence argued that the characterization of the obsidian supports arguments of the adaptive abilities to "new, local resources." Yet, whether this site does reflect the first human imprints on the landscape needs further study. Regardless of its age (and this has yet to be established) the first occupants exploited obsidian sources near to
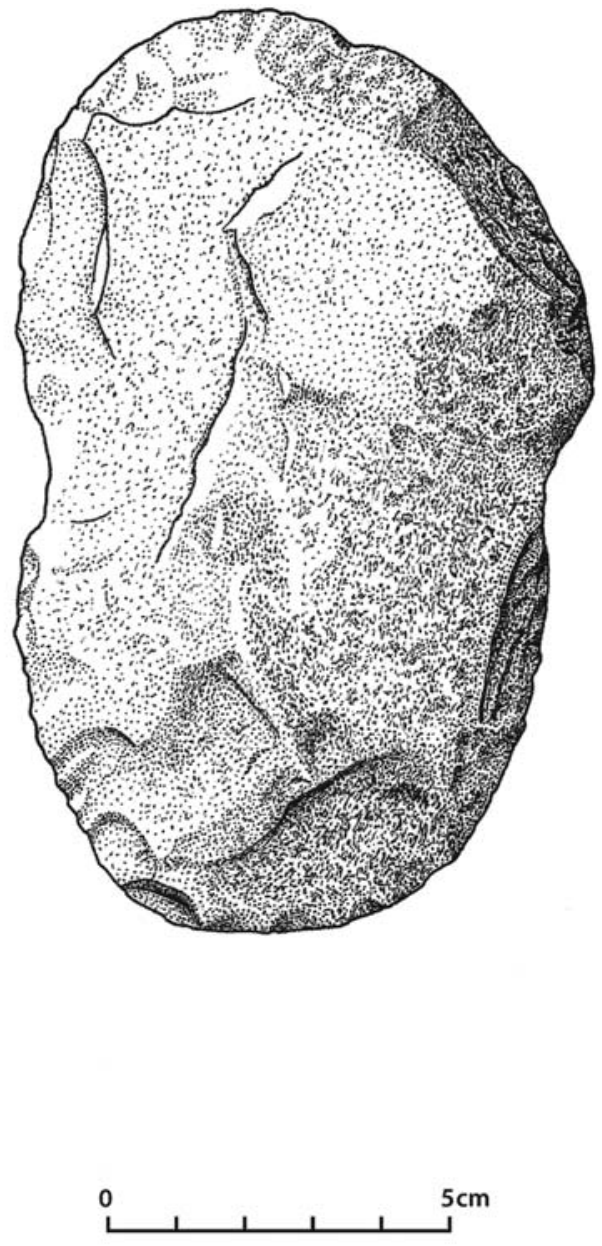

hand, and the amount of obsidian was related to the source's distance from the site. Torrence argued that the obsidian exploitation and use backs up claims for mobility. She argued that the evidence "indicates that they were highly flexible in terms of their subsistence patterns and well adapted to both tropical forest and coastal resources. We infer that they were also highly mobile" (Torrence et al. 2004:125). It is argued that such a model makes "good sense during the early stages of occupation with an unfamiliar landscape" 
(Torrence et al. 2004:125). Yet, it can also be argued that this strategy also existed for the next 20,000 years in New Britain as well.

BUANG MERABAK. The site of Buang Merabak (PNG National Museum site code EFP) is located halfway along the east coast of New Ireland. It is a large limestone cave $200 \mathrm{~m}$ from and about $150 \mathrm{~m}$ above sea level. It was first excavated by the late Andre Rosenfeld in 1985 (Rosenfeld 1997) as part of the Lapita Homeland Project and afterward by Matthew Leavesley in 2001 and 2002 (Leavesley et al. 2002, Leavesley and Chappell 2004, Leavesley 2005). The earliest evidence of occupation, found in Unit 4, is dated to 39,500 B.P. (Leavesley and Chappell 2004). Unit 4 lasts until 28,000 B.P. (Leavesley 2004). The material from this unit suggests low intensity of site use and a narrow range of terrestrial species, with faunal remains of cave-dwelling bat, Dobsonia anderseni, predominating (Leavesley 2004, 2007). It is argued here that it was the bats that enticed people to this cave because people went there to catch and consume them. This is in contrast to later periods at 20,000 B.P. where people brought their own protein with them, such as possums (Phalanger orientalis).

From Rosenfeld's excavated material, Balean (1989) argued that the earlier deposits contained larger Turbo shells, which meant targeted selection, compared with later levels. Leavesley's excavations confirmed that shellfish was also consumed in all levels of Buang Merabak (Pritchard and Leavesley 2004:271275). Fish remains were also found in those earlier levels, albeit few in number (one vertebra of Thunnidae/katsuwonid [Schmidt 2004]). A perforated shark's tooth was also found in the bottom unit of the site, suggesting the earliest ornament found in Sahul and one of the earliest examples of aesthetic symbolic behavior by our species (Leavesley 2007). Apart from being indicative of modern behavior, it also demonstrates an ability to catch a tiger shark, a hazardous activity (assuming the find was not opportunistic). Leavesley argued that, on the basis of exploitation, occupation was by "small highly mobile groups of hunter-gatherers who were exploiting both inland and coastal resources" (Leavesley 2007:310).
MATENkUPкum. Matenkupkum (PNG National Museum site code EFS) is a cave site found on the southeast coast of New Ireland (Summerhayes and Allen 1993, Allen and Gosden 1996:186) dated to over 35,000 years B.P. (Chappell 2000: table 1). It was first excavated in 1985 as part of the Lapita Homeland Project (Gosden and Robertson 1991) and again in 1988 by Chris Gosden and Jim Allen. The basal Unit 7 dates from ca. 35,000 to 32,000 B.P. This is overlain by Unit 6, which dates to 21,000 B.P. Evidence of colonization would thus be found only in Unit 7, which contained shell remains, land animals, and fish. Robertson (Gosden and Robertson 1991) analyzed the shell remains and argued for a diminution of large Turbo shells over time, implying a collection strategy focusing on the larger shells.

\section{What Can We Measure?}

Can we actually measure the impact that peoples made on the environment as a result of the colonization process? It is apparent that a lot of what we measure is a product of temporal resolution, and indeed what we are measuring can be many thousands of years after initial colonization. Is this the best resolution we can expect? The answer is probably yes, and to be realistic we are NOT measuring the "footprints" of colonizers when they first got off the canoe, but we are measuring the impact that people had on the environment after the initial colonization. It is stressed again that colonization is a process and not an event! The evidence presented below suggests that on the coast any impact people had on the environment was minimal, and indeed any impacts are measured over a period of 20,000 years. In the higher-altitude areas we are witnessing the footprints, here used as a metaphor for the impact of people.

\section{Little Evidence of an Impact on the Coastal Environment: Data from the Bismarck Archipelago}

There are no coastal sites from mainland New Guinea that can provide data with which to assess human impacts on the coastal resources for this crucial early period of time. 
Only a couple of sites from New Ireland provide data that can be used to assess the impact early people had on the coastal resources. The data suggest that there was little impact on coastal resources, with any change seen only after 20,000 years of occupation. This is hardly measuring a colonization impact. Jim Allen (1997:35), for instance, in Historical Ecology in the Pacific Islands, noted that the earliest sites from New Ireland, Matenkupkum, Buang Merabak, and Matenbek (later in time: earliest occupation begins at ca. 20,000 B.P.) "all contain large Turbo shells from their earliest deposits." Allen (1997:35) wrote that these "shells suggest that the reefs in front of these sites were discriminately collected by the earliest colonists in New Ireland." Although Gosden and Robertson (1991) argued that evidence from the shell assemblage at Matenkupkum reflects the conscious collection of the largest available shellfish from the southern New Ireland reefs, resulting in a general diminution in the size of available shellfish, the only change in shell size (reduction) came in deposits dated 20,000 years after the initial colonization. Resolution is a problem in identifying colonizing impacts on the environment, a point identified by $\mathrm{Al}-$ len (1997:36): "We are unable to differentiate either the size or frequency of this species between any periods during the first 10,000 to 12,000 years of deposition in Matenkupkum or between these levels and the earliest levels in Matenbek." In a recent paper he and Jim O'Connell argued for very low levels of human predation: "The large size of shells in the New Ireland samples suggest low levels of exploitation by relatively mobile human foragers" (O'Connell and Allen 2007:401). Thus any major changes in resource selection in those coastal sites occur between 20,000 and 18,000 B.P., with "more intensive use of reef resources and the reduction in the size and number of these Turbo" (Allen 1997:36). This occurs at the same time as other major events in the Bismarck Archipelago, such as the translocation of animal species into the Bismarck Archipelago (Matisoo-Smith et al., this issue) and the beginning of the longdistance exchange of obsidian within the archipelago (see Summerhayes [2007a] for a discussion).
The lack of an "environmental impact signature" for these early peoples may reflect the nature of their society but could also tell us more about the environment they faced and choices they made. The environmental reconstructions of the Bismarck Archipelago and Solomon Islands suggest that they had a remarkably depauperate biota compared with New Guinea (Allen 2000). Therefore, we might expect to find a more marked signature of human dispersal because human colonists had to adjust their adaptive strategies in line with the available resources. Although aspects of a new adaptive strategy do appear in the archaeological record subsequent to the process of initial colonization, seen for instance in the translocation of animals and the transfer of obsidian (see Summerhayes 2007a), the colonization and subsequent adaptation phase itself is notable for its relative lack of notable environmental manipulation. This is partly due to the lack of and restricted distribution of terrestrial protein.

Before the introduction by people of the Northern Common Cuscus (Phalanger orientalis) at 20,000 B.P., New Ireland contained few protein resources that existed in relatively high-density localized patches within the landscape. When people first migrated to New Ireland the only terrestrial fauna included a relatively small number of bats, rats, and reptiles (Flannery and White 1991, Allen 2000). One protein resource that did exist in high-density patches was flying foxes, or bats. The largest species was the Flying-Fox (Pteropus sp.), but these were probably difficult to catch in large numbers because they congregate in the tops of the largest trees. In such cases the use of a projectile may result in a kill, although it would have also resulted in the dispersal of the rest of the colony. However, one species, the Bare-Backed Bat (Dobsonia anderseni), congregates in caves during the day, making them a prime target for the human hunter because they are relatively easy to catch using simple technologies. Strategies such as placing barriers across exits or smoking caves can be practiced with minimal technology and can produce high yields of bat meat.

Although bat caves can be found throughout New Ireland, the highest density of 
potential bat-colony caves is in the Lelet Plateau, central New Ireland. To venture farther north of this region was to move into areas of effectively lower-density protein resources. On this basis it has been argued by Leavesley (2004) that the relative reduction of potential bat-colony caves in northern New Ireland is likely to have limited the degree to which the landscape was used by human hunters before the introduction of the cuscus (Phalanger orientalis).

Thus, people had a minimal impact, and this can be seen in the rate of extinctions seen in the archaeological record. In New Ireland, one rodent and a range of bird species have been reported as extinct/extirpated, yet many of these extinctions occurred well after colonization. Examples include the rodent Rattus mordax sanila, a petrel, hawk, megapode, quail, four rails, cockatoo, two owls, and a crow. Based on other studies of Pacific avifauna it is suspected that these extinctions/extirpations are anthropogenic in nature, although this suspicion is as yet undetermined (Steadman et al. 1999). First, as Steadman pointed out, it is unclear when species disappeared (Steadman et al. 1999:2567). He noted that only $2 \%$ of the bird bone from the five sites analyzed from New Ireland is older than 15,000 B.P., "at which time humans already had occupied New Ireland for 20,000 years."

It can be argued that the resources available in island New Guinea would have supported only a small mobile population with low consumption levels. As outlined in Summerhayes (2007b:144) the populations of the Bismarck Archipelago are not envisaged to have been large. New Ireland has a land mass of $8,650 \mathrm{~km}^{2}$, spread out over $320 \mathrm{~km}$ (the length of New Ireland), a lot of it difficult to access. For instance, much of the southern one-third of New Ireland is mountainous and difficult to access, with the highest peak over $1,200 \mathrm{~m}$. It is argued that with a depauperate fauna, even with the introductions of Phalanger orientalis at ca. 20,000 B.P., the biomass would not have supported large populations of hunter-gatherers. Even with hunting range territories of $10 \mathrm{~km}^{2}$ for each hunter-gatherer group at any one time, this would have resulted in the number of hunting catchments on the order of just over a hundred. Each of these catchments could possibly support a dozen people.

The mobility of these early colonizers can be seen in the assemblages of island Melanesia. The evidence from Kupona $\mathrm{Na}$ dari indicates relatively high mobility manifest in the wide range of stone resources utilized for the production of stone tools (Torrence et al. 2004) and is consistent with the evidence from Yombon (Pavlides 2004). Yombon is an inland open site located on the south side of the Whiteman Mountain Range, 2 days walk from the coast and occupied by 35,000 B.P. The evidence from Yombon also indicates that the first colonists did not see the inland rain forest as a barrier to movement (Pavlides 2004), although they might not have initially gone inland on a regular basis (Summerhayes 2007a:11-12). The result of this is that any footprint we might expect to find in New Britain is not going to be tied to the coast.

\section{Evidence of an Impact on the Environment: Footprints in the Mountains of New Guinea, Kosipe Valley}

Where human-induced environmental change can be measured is from the higheraltitude site of Kosipe. One of the best records of human-induced environmental change is found there. This record has been disentangled through a mix of paleoecological, archaeological, and ethnographic research, aided by the preservation of deep, pollen-rich sediment sequences extending well into the Pleistocene.

Kosipe Valley has the earliest evidence of landscape modification in New Guinea. Early human occupation is dated to at least 35,000 B.P. $(35,049 \pm 670$ B.P. [Wk-17901]) but could be earlier. Pollen research at Kosipe by Hope demonstrated forest clearance through burning before 36,000 B.P. $(36,500 \pm 400$ B.P. [OZE-451] [see Fairbairn et al. 2006:376]). It has been argued by Hope that such fire clearance was not natural, with fires occurring in the mid- to upper-montane Nothofagus and Elaeocarpus forests (see Fairbairn et al. [2006:376] for details). Such firing 
would have had an effect, with erosion resulting in infilling of the lake covering the valley floor, resulting in the swamp we see today (Hope in press). On the slopes, patches of grass and tree ferns are evident from the pollen cores (Hope and Golson 1995:822).

Though analysis is at a very early stage at the time of this writing, the recovered archaeological evidence indicates the presence of small campsites around the valley sides, with campfires, stone tools (waisted axes), animal bone fragments, all as yet unidentifiable, and, in some sites, Pandanus nutshell fragments in 30,000-year contexts $(30,575 \pm 399$ B.P. [Wk-17261] and 30,727 \pm 395 B.P. [Wk-18233]). Site contents suggest multiple activities, including wood and nut gathering, some form of hunting, stone tool preparation, and the use of fire for heating. These possible home bases, accompanied by isolated activity, mainly stone axes, may indicate places where specific activities, such as hunting or plant gathering, took place. Little further detail is possible at the moment.

A preliminary interpretation of lifeways in the valley suggests that subsistence involved some form of foraging/collection strategy. White et al. (1970) suggested that this may have been targeted on the use of Pandanus, but the evidence is too sparse currently to test that notion. It remains unclear what form of mobility was involved, but application of optimal foraging theory suggests regular residential mobility to allow use of widely distributed resource patches (see discussion by Denham and Barton [2006]). Seasonality of occupation is a contentious topic, with seasonal movement to exploit the Pandanus fruits in the locally recognized November-December production season suggested at Kosipe by several authors (White et al. 1970, Hope and Golson 1995, Fairbairn et al. 2006), perhaps even underpinning the movement of people through the area (White et al. 1970). Denham (2007) recently rejected this notion, preferring a less temporally constrained generalized foraging pattern. However, Denham used data from other parts of New Guinea that may have little relevance for understanding the more southerly and notably more seasonal environ- ment of the Owen Stanley Range. With a complete lack of comparable sites of similar age and preservation from other regions of New Guinea, the probable geographical variation in seasonality of both occupation and plant production cycles is likely to remain obscure in the near future.

Apart from the impact that fire had on the environment, hunting and gathering practices of course always will affect the environments on which they are targeted, with removal of individuals, modification of population structure, reproductive potential, and ecological relations. Sites appear sparsely distributed, and we must suspect a small population. Lack of similar landscape preservation circumstances and limited exploration leave us totally unclear about the presence of humans beyond the valley's confines. At face value such a population would leave a light ecological footprint if restricted to hunting and gathering.

Yet evidence exists for deliberate landscape firing activities in the form of 30,000-40,000 B.P. microcharcoal peaks in the sediments of the Kosipe Swamp, combined with the presence of some possible indicators of forest openings in the form of grass phytoliths (Fairbairn et al. 2006). Microcharcoal accumulates in sediments when vegetation within a catchment is burned, but the key question is whether that burning has a clear link with human agency. Analysis of numerous microcharcoal records across New Guinea has suggested that Pleistocene vegetation burning follows no clear chronological pattern, being asynchronous across the island and lacking clear connection with a single climatic event, such as periods of drying. When added to the dampness of the natural highland vegetation, the evidence suggests that the most probable firing agent was people, and the new dates at Kosipe indicate for the first time that people's arrival was synchronous with these earliest firing events. Burning would have opened up the vegetation and may have encouraged herbaceous vegetation for grazing animals; however, the small size of Kosipe's microcharcoal peaks in relation to later evidence of burning (see following) suggests that burning may have been of limited spatial extent. Thus al- 
though some form of burning, and thus landscape management, is indicated, it may have had limited and localized impact on the Kosipe biota. Perhaps similar localized vegetation change was also found in the Baliem Valley, in the Indonesian province of Papua, where pre-30,000 B.P. microcharcoal records are also found.

The presence of waisted axes and Pandanus at Kosipe suggests that the axes may have been used to clear vegetation to manage Pandanus, a claim first put forward by Groube (1989) and reinforced by Hope and Golson (1995:823). Groube (1989) suggested that the first colonists of New Guinea arrived equipped with the technological capacity to occupy the inland rain forests. The acceptance of this model suggests that the first colonists of New Guinea were not tied to the coastal zone, thereby reducing their impact on that part of the lowland landscape. Groube argued (1989:298) that "the forest dwellers of northern Sahuland had developed strategies of survival in the forest which involved alteration of the existing vegetation.... What is certain is that the forest dwellers of northern Sahuland were not passive in their environment but actively altered it."

\section{Effects of Pleistocene Colonization on the Environment}

Site visibility, strategies for sustaining an existence, local vegetation, and the extent of archaeological and paleoecologcal resources are all important variables that need to be taken into consideration when measuring any impact on the environment by early colonists. The impact seen at Kosipe is due to agroforestry strategies of land management in an environment where fire is possible and identifiable in the archaeological and paleoecological record. The Pandanus species that were sought in high-altitude Papua during the late Pleistocene are not found in coastal New Ireland. The use of fire as a strategy in land management, as witnessed during the first occupation at Kosipe, would be difficult in coastal "rain forests." Even if it was possible, such as during an El Niño drought (as witnessed in the late 1990s in New Ireland), there has been limited paleoecological research undertaken to identify it.

In New Britain, on the other hand, impacts on the environment are more difficult to assess. Much of what we measure is sandwiched between volcanic tephras, marking a volcanic and changing landscape, highly acidic and not allowing the preservation of bones and organics. Here, the archaeological evidence is mostly made up of stone tools. Models constructing the nature of the first inhabitants based on the technology and distribution of stone are of a different nature than those models from Kosipe or those based on the rich midden sites from $\mathrm{New}$ Ireland. These latter sites are mostly wellstratified limestone cave deposits where organics have a greater survival rate. Yet even here, measuring changes in the archaeological record that are related to human impacts is difficult for the first twenty millennia of occupation.

\section{LAPITA COLONIZATION LANDSCAPES}

The colonization of the western Pacific by Austronesian-speaking peoples with a material culture known as Lapita had a different and more immediate impact on the environment. The measurement of this impact is partially a result of chronological resolution: we are measuring events that occurred 3,000 years ago rather than 40,000 . It is also a result of the nature of the settlement and economy of these colonizing peoples and the locations they settled.

Within the Bismarck Archipelago alone there are over 90 find spots of dentatestamped pottery, the archaeological signature of Lapita occupation (see Figures 3 and 4). These find spots range from just a few sherds of pottery to evidence of large Lapita settlements (see Summerhayes 2007b).

We review Lapita impacts on the environment by looking, first, at their impact on local fauna, and second, at the impact on the environment. We restrict our assessment of Lapita colonization to a region that had already been inhabited for 40,000 years, the Bismarck Archipelago, although some reference will be made to Remote Oceania in regard to extinc- 


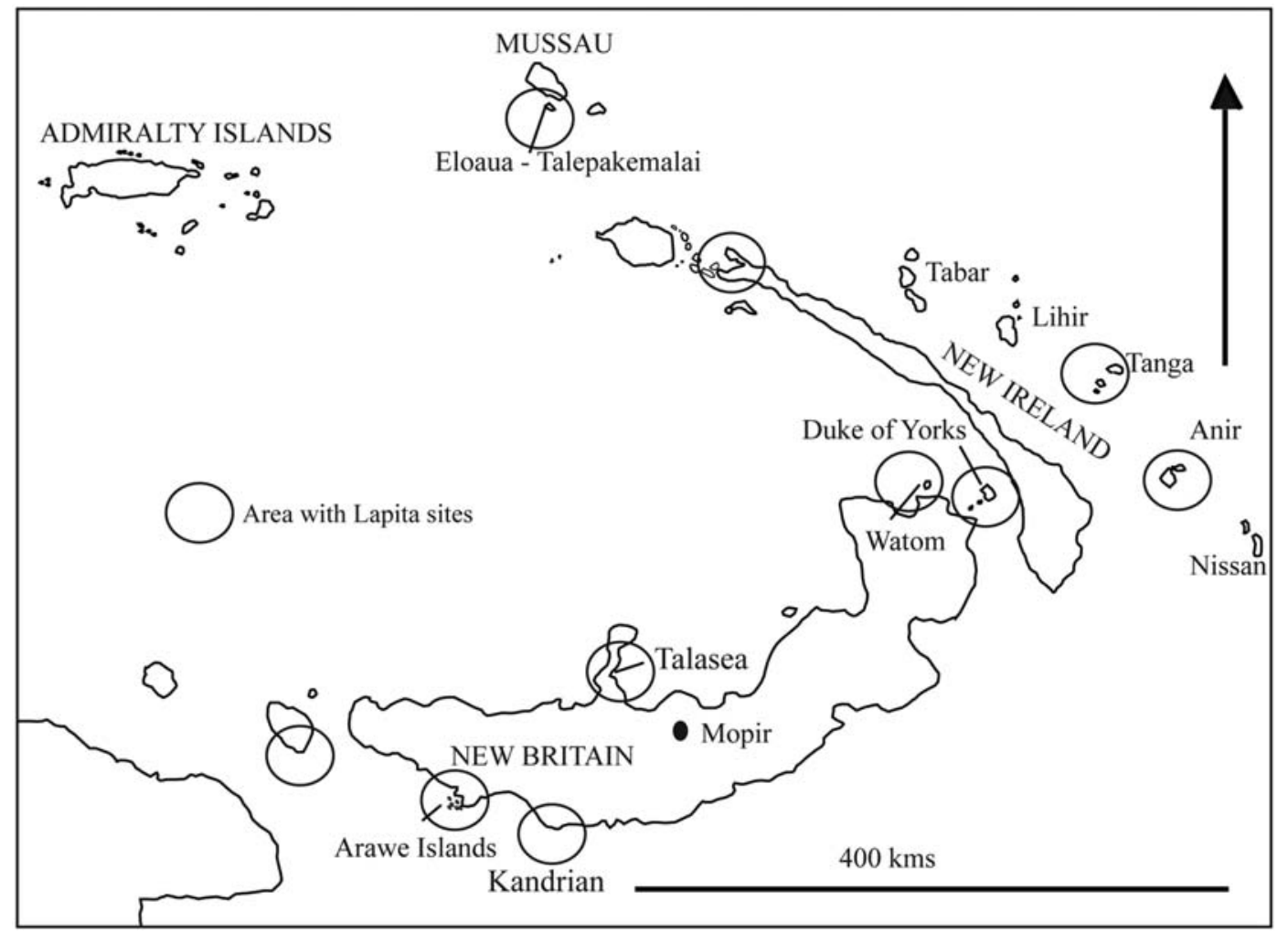

Figure 3. Lapita sites in the Bismarck Archipelago.

tions. We also restrict the review to evidence from those sites with the earliest record of Lapita colonization: the Arawe Islands, Mussau, and Anir.

\section{Faunal Extinctions}

The leading expert on bird loss on Pacific islands, David Steadman, makes it clear that birds are lost to, first, the predation of people and non-native animals (pig, rats, and dogs), and second, the alteration of forests and changes to the environment leading to the removal or alteration of forests (Steadman 1995:1123).

The impact that these colonizing Lapita populations made on indigenous bird populations, however, varied between Near and Remote Oceania, the biogeographical divide labeled by Roger Green and Andrew Pawley over 40 years ago (Pawley and Green 1973:4). The former area comprises New Guinea, the Bismarck Archipelago, and the Solomons down to San Cristobal, forming a chain of archipelagos and intervisible landmasses separated from Remote Oceania by a $350 \mathrm{~km}$ water gap beginning with the Reef/ Santa Cruz Group in the eastern Solomon Islands (Pawley and Green 1973:4). They considered the boundary important for a number of reasons. The first is biogeographical: the "cutoff point in the natural distribution of animal and plant species" with diversity in flora and fauna diminishes east of the Solomons. The second is that the boundary also marks the edge of human colonization in the Pleistocene (Pawley and Green 1973:4-5). Although Near Oceania had a human pres- 


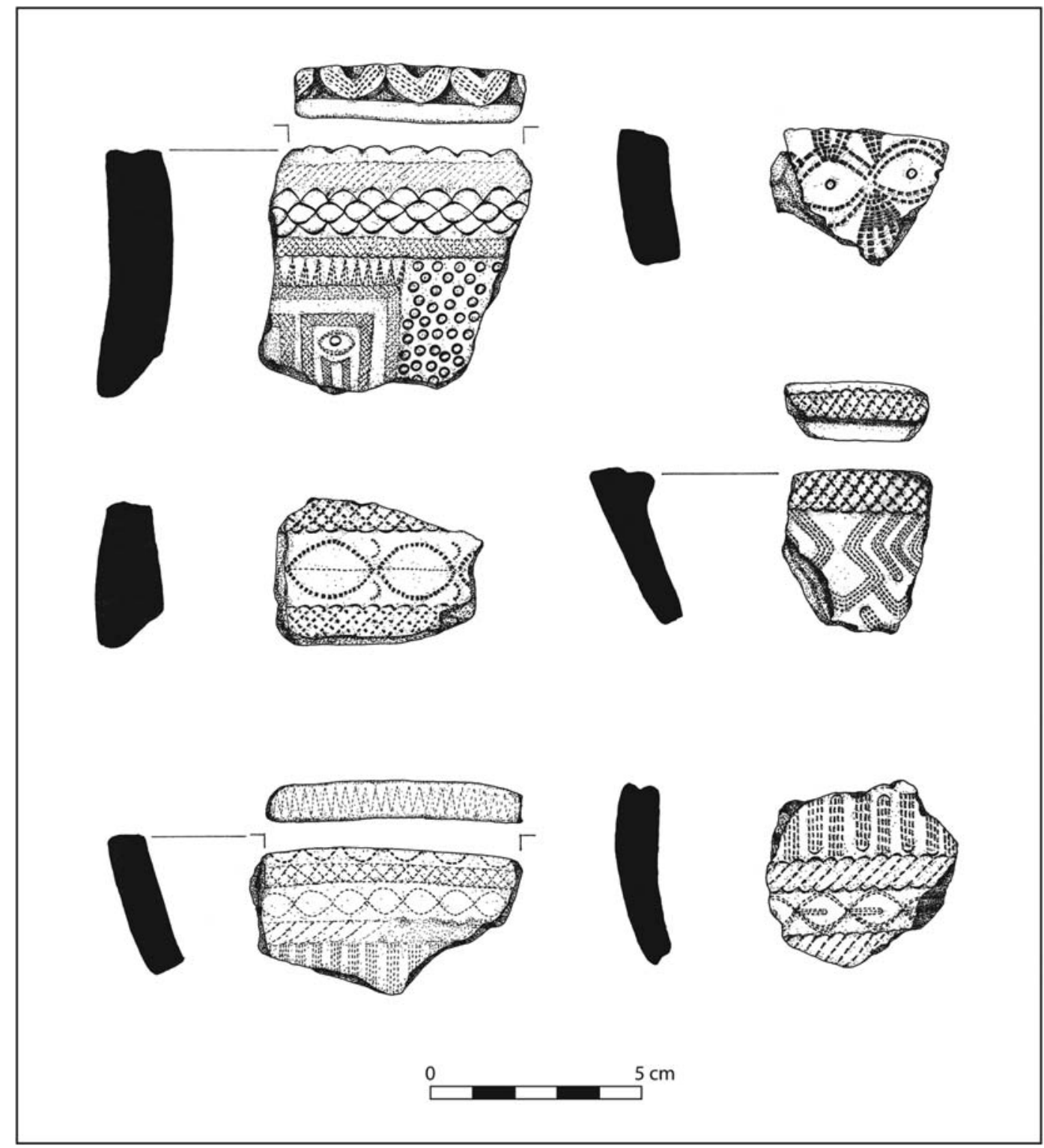

Figure 4. Lapita dentate-stamped pottery from Kamgot (site code ERA).

ence for 40,000 years, Remote Oceania was colonized for the first time only just over 3,000 years ago.

Steadman made the point that Lapita populations colonizing the islands of the Bismarck Archipelago entered an area that "already withstood tens of millennia of human activity" (Steadman et al. 1999:2567, Steadman 2006:127). He argues that in Near Oceania bird populations may have evolved "alongside native rodents," thus being exposed to predation before the appearance of people (Steadman 2006:127). Whereas Steadman has estimated that New Ireland may 
have lost more than $20 \%$ of species with the advent of people, in Polynesia the percentage was much higher, at 50\%-90\% (Steadman 2006:127). The latter he refers to as a "Blitzkrieg" (Steadman 1999). Why? Because as he pointed out, "these birds evolved without mammalian predators and thus had little defence against humans and their rats, dogs and pigs" (Steadman 2006:405). For instance, the number of extinct and extirpated seabirds and land birds is much less for Mussau (Near Oceania) than for Tikopia (Remote Oceania) (Steadman and Kirch 1998, Steadman 2006:129). He argues that islands in Remote Oceania have "lost most of their endemic species of birds since humans arrived" (Steadman et al. 1999:2563).

Extinctions were not limited to birds alone, with other animals disappearing as people arrived. Reptiles were affected, with a species of iguana disappearing from Tonga and Fiji (Clark and Anderson 2001, Steadman et al. 2002) and a large land-dwelling crocodile from New Caledonia (Kirch 1997:224).

Only a few species of birds were added by the Lapita populations. Chicken was brought in with those colonizers. Although it has been noted that finds of chicken are rare in Near Oceanic Lapita sites (Storey et al. 2008), there is evidence of chicken in Mussau (Steadman 2006:128). This was an introduction from Southeast Asia. Another introduction, although from much closer to home, was the cassowary into New Britain, with remains of Casuarius cf. casuaris found at the Lapita site of Apalo, in the Arawe Islands, New Britain (Steadman 2006:130). This species of cassowary is not found on New Britain today; only $C$. bennetti is present.

Other animal introductions, or "translocations," included the pig, dog, and Rattus exulans (Summerhayes 2007b). All three are found from the Anir Lapita assemblages from the earliest levels. The first two were direct introductions from Southeast Asia. Also, on the Anir Island Group there is evidence of the local movement of animals, with possum (Phalanger orientalis) and wallaby (Thylogale browni) at the Kamgot site (site code ERA). These animals were probably brought with the first human occupants to Anir some
3,300 years ago. Despite extensive excavations on Anir by Summerhayes, the first evidence of occupation is associated with Lapita settlements, not before.

\section{Effect on the Environment}

There has been little paleobotanical work on measuring environmental change as a result of human arrivals. Little if any relevant work has been undertaken in the Bismarck Archipelago (see Hope et al. 1999). A few references exist for New Caledonia, Aneityum, and Fiji in Remote Oceania (Hope and Spriggs 1992, Stevenson 2004; see Hope at al. 1999) that confirm an alteration of the environment with the advent of colonization (an increase in charcoal as an indication of fire, and/or changes in pollen indicating the appearance of grassland).

The nature of human existence in these pristine environments will have an impact on the local resources. These peoples were horticulturalists. Although it has been argued that there was no convincing evidence for horticulture, the presence of pig, chicken, and dog as introduced domesticates is thought to be good indicators of agriculture in those early Lapita societies. People did eat more than what they grew, and a strong maritime diet is seen in the early midden sites. This would be expected with early Lapita settlements located next to the coast. From the Lapita site of Kamgot, for instance, fish bone dominates the faunal assemblage. The most popular fishes were inshore varieties such as Scaridae and Diodontidae. Most of the fishing was inshore or from the reef, although shark, tuna, dolphin, turtle, and barracuda were also found. A similar exploitation is seen from the Mussau assemblages (Kirch et al. 1991). Fishhooks were recovered from Anir (Szabo and Summerhayes 2002) and Mussau.

Sites farther east in Fiji and Tonga also suggest a seaward-oriented economy, yet some archaeologists suggest that these early settlers were strandloopers, moving from island to island exploiting the natural resources and moving on when these were depleted (Groube 1971, Burley et al. 2001:102). Burley 
et al. (2001:102) also argue that these early settlers had a mobile maritime adaptation. There is no doubt that in these islands the colonizing groups had an effect on marine fauna. This has been recorded, for instance, on Tonga and Lakeba, Fiji, with an overharvesting of shellfish and turtle (Poulsen 1987, Spennemann 1987, Best 1984). Yet, as noted above, this adaptation to the sea is no different from the scenarios farther west except that the Lapita colonists in Near Oceania had a greater choice of land mammals to supplement their diet. Agriculture would have played a role in both situations but to varying degrees.

Direct evidence for agriculture does exist in the early Lapita colonizing societies, with recent residue studies on Lapita pottery and/ or associated sediments. The first study, using starch residue analysis on plain pottery from Kamgot (Crowther 2005), provided evidence for Colocasia esculenta (taro). The second study, using phytolith analysis on sediments from the Lapita site of Watom (Lentfer and Green 2004), demonstrated the presence of banana (Eumusa). Another recent study using starch residue analysis on soils has identified Araceae (aroids) from a Lapita site on Uripiv Island off the northeast coast of Malekula, Vanuatu (Horrocks and Bedford 2005).

The construction of Lapita settlements and the introduction of agriculture into these island systems necessitated changing the landscape. Three major studies on Lapita settlement systems have been undertaken at the edges of the Bismarck Archipelago: Arawe Islands, Mussau, and the Anir Islands.

ARAWE. Although there is evidence of human presence in the Arawe Islands before Lapita, with mid-Holocene occupation at Lolmo Cave (Gosden et al. 1994), major changes to landscape are only witnessed with Lapita occupation. Work by Chris Gosden has demonstrated the existence of stilt village occupation in the Arawe Islands (Gosden and Webb 1994). Gosden identified the location of Lapita sites on the lee side of the islands either on or immediately behind the sandy beaches. A number of sites were excavated including Apalo (PNG National Museum site code FOJ) on Kumbun Island and Makekur
(PNG National Museum site code FOH) on Adwe Island. "At Apalo a $60 \mathrm{~m}$-wide expanse of beach and swamp separated the ocean from the $10 \mathrm{~m}$-high limestone cliffs.... At the foot of the cliff is a flat, swampy area, composed of partially vegetated, dark brown clays" (Gosden and Webb 1994:36) (see Figure 5).

During the occupation at Apalo, the settlements would have been on the limestone reef platforms some $20 \mathrm{~m}$ wide that slope toward the sea, some 30-60 $\mathrm{m}$ from the cliff (Gosden and Webb 1994:33). Gosden argues that during that period there was a higher sea stand and that at high tide houses had between 1.5 and $2 \mathrm{~m}$ of water beneath them.

Gosden and Webb (1994:40) argue that the alteration of forests to create gardens created erosion, with the eroded clays depositing behind the reef and stilt settlement locations. The creating of gardens meant cutting the virgin forest for swidden (slash and burn) horticulture. Kumbun and Adwe islands are raised limestone islands with fragile ecosystems. The thin soil covering is allophanic, derived from volcanic tephra. The erosion caused from forest clearance was catastrophic, with soil/clay built up behind the stilt houses and their midden rubbish forming a damming effect, and the results of accumulation of clay at the base of the cliff infilling the lagoon (Gosden and Webb 1994:41). In short, it was a change to the landscape caused by human intervention as a result of cultural and economic factors: "The house piles have a baffling effect; by reducing the strength of the waves and tidal currents underneath the houses, sand that would otherwise have been continuously transported through the area is instead trapped to form sand banks. Any artefact material or rubbish that is dropped or thrown from the houses adds to the sediment accumulating beneath them" (Gosden and Webb 1994:40). "Human activity thus caused the beach areas to increase in size and to become more favourable sites for habitation. The growth of the coastal zone was an accidental by-product of the clearance of natural vegetation, presumably to accommodate the fruit and nut crops found at Apalo, together with root crops such as taro for which we 


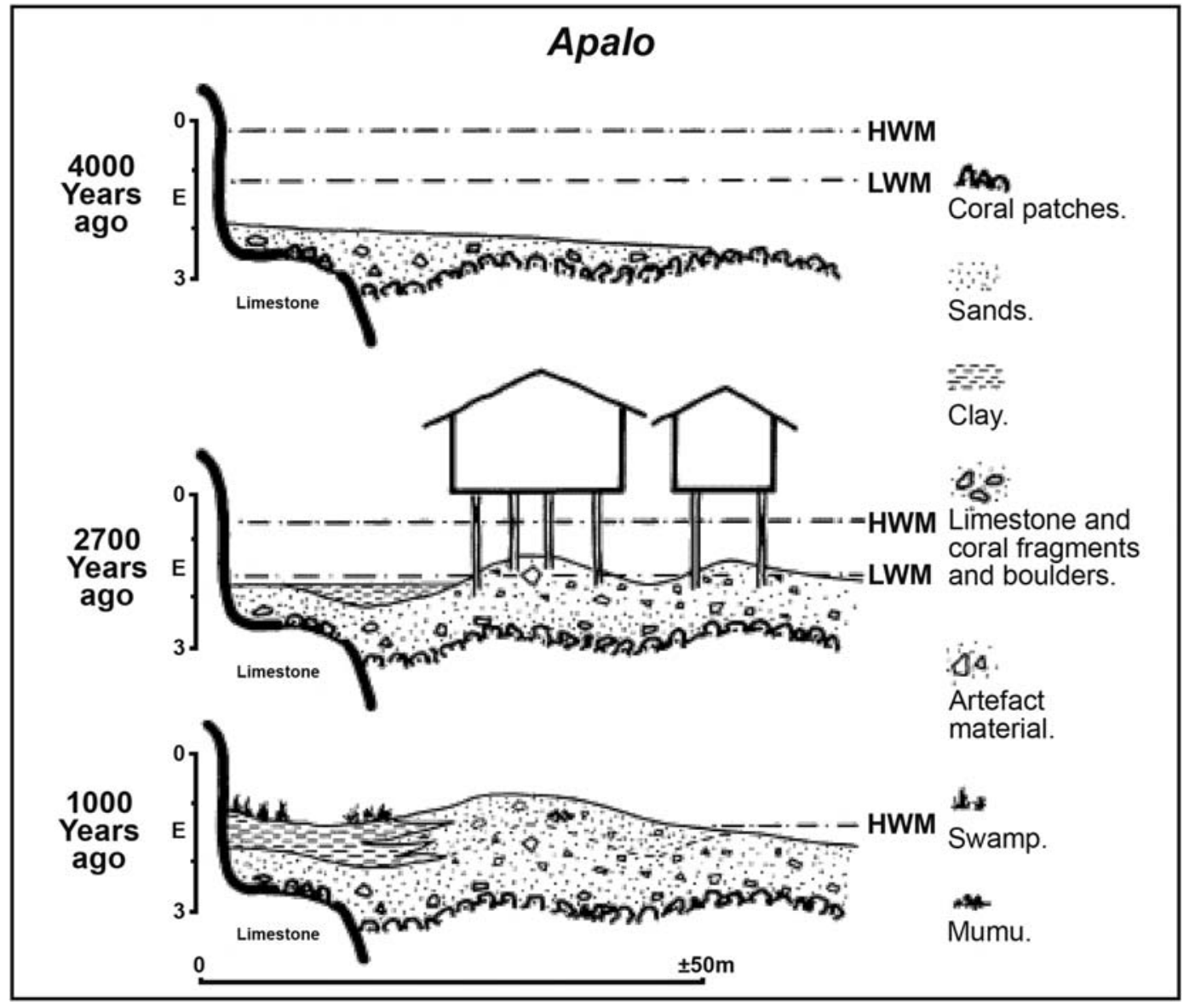

Figure 5. Site formation processes at Apalo (site code FOJ) (courtesy of Chris Gosden [Gosden and Webb 1994]).

have no direct evidence at present" (Gosden and Webb 1994:48). There is no evidence at all for the existence of stilt village occupation before Lapita occupation!

MUSSAU. Evidence for stilt house occupation was also found on the small islands just offshore from the island of Mussau. Three Lapita villages would have been in sight of each other: Talepakemalai (site code ECA) and Etakosarai (site code ECB) on Eloaua Island, and Etapakengaroasa (site code EHB) on Emanamus Islands, lying just south of the major island of Mussau (Kirch 2001). ECA (Kirch calls it a "village") covered a total of $82,000 \mathrm{~m}^{2}$ compared with ECB and
EHB (Kirch calls them "hamlets"), covering $3,000 \mathrm{~m}^{2}$ and $1,000 \mathrm{~m}^{2}$, respectively (Kirch 2001:142).

To understand the site Kirch undertook a research strategy that included geomorphological processes and the laying out of excavation units across the landscape using transects (Kirch 2001:131). On the basis of Pacific sealevel studies and an examination of wave-cut notches from Eloaua, Kirch modeled a higher sea stand of 1 to $2 \mathrm{~m}$ during Lapita occupation. As sea level dropped, the coastal terrace prograded. Kirch argued that the covering of the stilt structures located originally on the "subtidal sandy reef flat" at Talepakemalai 
had less to do with people than with natural events (Kirch 2001:132). Kirch provided a convincing argument that a rapid drop in sea level resulted in the erosion of an outer reef and platform, "thus generating an increased quantity of calcareous sediment" (Kirch 2001:132). Thus Kirch argued that the generation of the beach has less to do with people than with natural events. These events covered the midden deposition of pottery, obsidian, and so on that accumulated over time. The area between these stilt structures and the beach was argued to have contained "a zone of fine-grained sediments deposited in a low energy sub-tidal environment" that trapped organic remains such as wood and coconuts (Kirch 2001:132).

Over time, by 2,800 B.P. as progradation occurred, the beach shifted away, and new stilt structures were built (see Figure 6). Kirch (2001:132) argues that by 2,500 B.P. the stilt village was abandoned, and as the beach further prograded the archaeological deposits were "flooded by a Ghyben-Herzberg aquifier," which in turn preserved them.

ANIR. The third example is from the Lapita site of Kamgot (PNG National Museum site code ERA), located at the western end of Babase Island, Anir. Babase is mostly volcanic, but its western end is raised limestone. Kamgot was originally located within an old lagoon, and the site spread over a sandy bar and a reef flat parallel to an outer reef (to the north) some $80 \mathrm{~m}$ away, and to the south a steep limestone rise some $150 \mathrm{~m}$ away. Today the site is $100 \mathrm{~m}$ in from the high-tide mark, with the old raised reef forming a raised beach front. Like Apalo, there is an accumulation of clays at the base of the steep rise, and the area is now swampy. Like Apalo, the removal of the forest sitting on top of the limestone resulted in erosion of the clays, resulting in the infilling of the ancient lagoon. Unlike Kumbun Island, however, the island of Babase is actively volcanic, with evidence of tectonic uplift. The base of the major pottery-bearing test pits at Kamgot is some $2.5 \mathrm{~m}$ above high-tide level (Summerhayes 2000:171). So changes to the environment are seen as a combination of human and natural processes.

\section{Effects of Lapita Colonization in the Bismarck Archipelago}

The appearance of Lapita settlements at 3,300 years ago in the Bismarck Archipelago marks something different to the region. The appearance of animals from Asia, horticulture, pottery, and a new settlement pattern is seen as a change from the economic and social structures that existed for the previous 35,000 years. These newcomers had a great impact on the environment, changing it to sustain a lifestyle. An important point made by Chris Gosden is that "Land use is culturally determined, arising from choices people make about how to provision the social system" (Gosden and Webb 1994:48). Indeed it would have been strange if no change was measured in the landscape.

\section{CONCLUSIONS}

In this paper we reviewed two different colonizing processes separated in time by thousands of years. In many ways we are comparing apples with oranges. Early colonizers entering New Guinea at 40,000 years ago were part of the movement of our species across the planet after their initial dispersal from Africa many millennia before. Their dispersal strategies were different. Their social and economic structures were not the same. Day-to-day existence in that world that Gosden (1993:133) so aptly described as without ethnographic parallel is only now being modeled on the basis of a handful of sites. Added to this are the problems of site visibility and temporal resolution. Changing landscapes over 40,000 years makes finding late Pleistocene sites difficult. From the handful we have at hand, occupation may be 1,000 to 5,000 years after initial colonization. However, as noted earlier, we are not measuring the "footprints" of colonizers when they first got off the canoe. We are measuring the impact that people had on the environment after the initial colonization.

The events at 3,300 years ago, on the other hand, are modeled on a different data set measuring dissimilar processes, by people equipped with different mind sets and tech- 

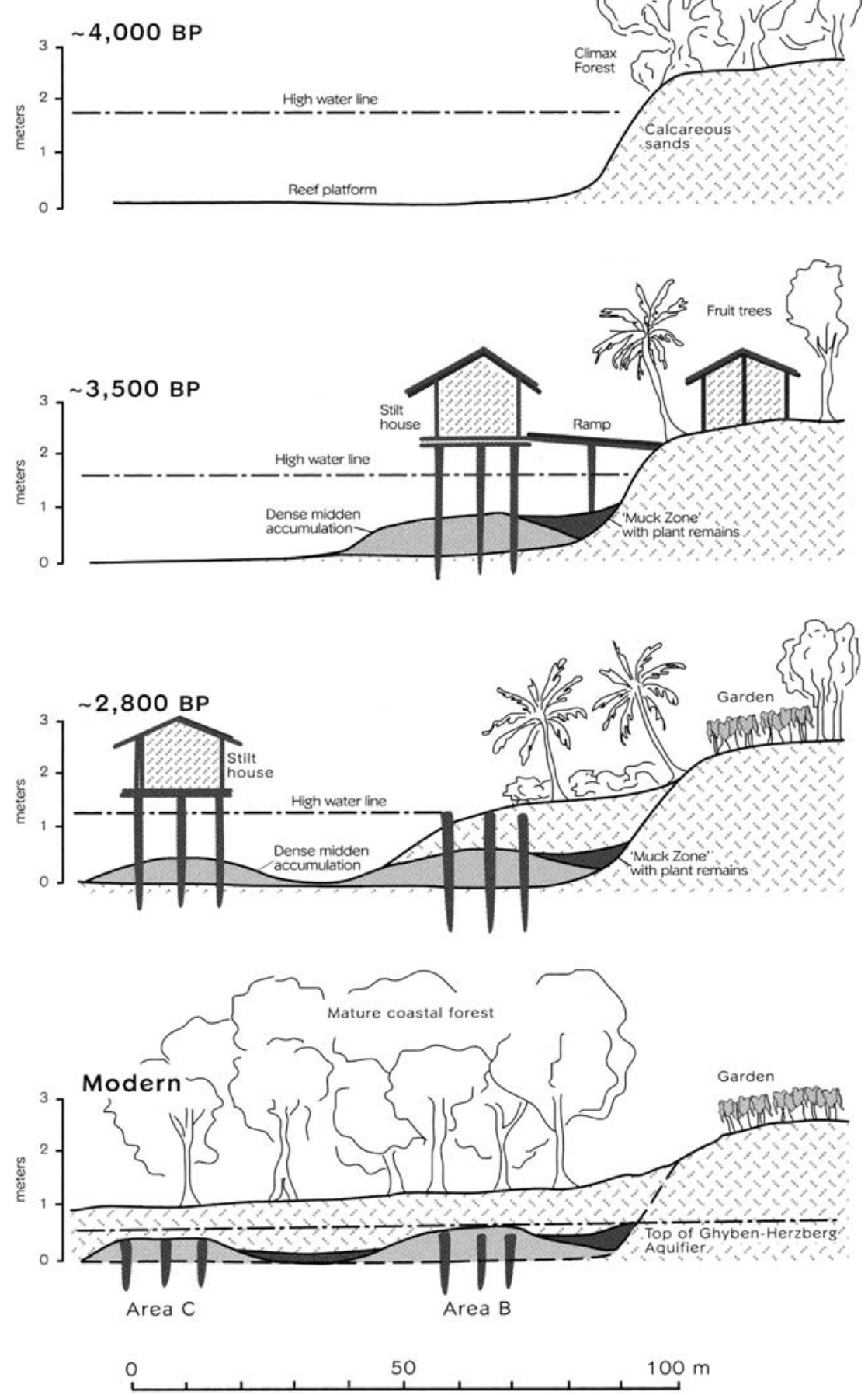

Figure 6. Site-formation processes at Talepakemalai (courtesy of Pat Kirch [Kirch 2001]). 
nology. We are lucky, though, that the evidence of their coastal habitation has been preserved for us to examine. Coastal occupation in a beach deposit in a handful of unique locations has preserved these footsteps. We cannot say the same for the occupants descended from the original populations who had inhabited the Bismarck Archipelago for thousands of years. Here we are restricted to a handful of cave and open sites that provide a unique glimpse into their world. Yet we still cannot model the interaction between these descendants and Lapita peoples at 3,000 years ago due to a lack of archaeological data. This is reflected not only in the different behaviors resulting in a different and perhaps "invisible" archaeological record but also in the paucity of archaeological work in this region by only a handful of archaeologists. To resolve these issues requires an increase in archaeological fieldworkers in Papua New Guinea from just the current handful currently engaged in active research.

\section{ACKNOWLEDGMENTS}

We thank Jim Robins and the National Research Institute of Papua New Guinea for facilitating our research in Papua New Guinea; and the National Museum and Art Gallery of Papua New Guinea with whom we have affiliation. From the latter institution we would like in particular to thank Herman Mandui (chief archaeologist) for his continued support. G.R.S. acknowledges the support of the Australian Research Council for his fieldwork on Anir, and the Royal Society of New Zealand for awarding a Marsden Fund grant to enable fieldwork at Kosipe and a 3-year postdoctoral fellowship for M.L. Many thanks to Associate Professor Richard Walter for his valuable comments on this paper, and Professors Chris Gosden and Pat Kirch for permission to use their illustrations (Figures 5 and 6).

\section{Literature Cited}

Allen, J. 1997. The impact of Pleistocene hunters and gatherers on the ecosystems of Australia and Melanesia: In tune with Nature? Pages 22-38 in P. V. Kirch and T. L. Hunt, eds. Historical ecology in the Pacific islands: Prehistoric environmental and landscape change. Yale University Press, New Haven, Connecticut.

. 2000. From beach to beach: The development of maritime economies in prehistoric Melanesia. Mod. Quat. Res. Southeast Asia 16:137-176.

Allen, J., and C. Gosden. 1996. Spheres of interaction and integration: Modelling the culture history of the Bismarck Archipelago. Pages 183-197 in J. Davidson, G. Irwin, F. Leach, A. Pawley, and D. Brown, eds. Oceanic culture history: Essays in honour of Roger Green. N. Z. J. Archaeol. Spec. Publ.

Allen, J., C. Gosden, and J. P. White. 1989. Human Pleistocene adaptations in the tropical island Pacific: Recent evidence from New Ireland, a greater Australian outlier. Antiquity 63:548-561.

Balean, C. 1989. Caves as refuge sites: An analysis of shell material from Buang Merabak, New Ireland. B.A. honours thesis, Australian National University, Canberra.

Best, S. 1984. Lakeba: The prehistory of a Fijian island. Ph.D. diss., University of Auckland, Auckland, New Zealand.

Burley, D. V., W. R. Dickinson, A. Barton, and R. Shutler. 2001. Lapita on the periphery. New data on old problems in the Kingdom of Tonga. Archaeol. Oceania 36:89-104.

Chappell, J. 2000. Pleistocene seedbeds of western Pacific maritime cultures. Mod. Quat. Res. Southeast Asia 16:77-98.

Clark, G., and A. Anderson. 2001. The pattern of Lapita settlement in Fiji. Archaeol. Oceania 36:77-88.

Crowther, A. 2005. Starch residues on undecorated Lapita pottery from Anir, New Ireland. Archaeol. Oceania 40:62-66.

Denham, T. 2007. Exploiting diversity: Plant exploitation and occupation in the interior of New Guinea during the Pleistocene. Archaeol. Oceania 42:41-48.

Denham, T., and H. Barton. 2006. The emergence of agriculture in New Guinea: Continuity from pre-existing foraging 
practices. Pages 237-264 in D. J. Kennett and B. Winterhalder, eds. Behavioral ecology and transition to agriculture. University of California Press, Berkeley.

Fairbairn, A., G. Hope, and G. Summerhayes. 2006. Pleistocene occupation of New Guinea's highland and subalpine environments. World Archaeol. 38:371-386.

Flannery, T. F., and J. P. White. 1991. Animal translocations. Natl. Geogr. Res. Explor. 7 (1): 96-113.

Gillieson, D., and M.-J. Mountain. 1983. Environmental history of Nombe rockshelter, Papua New Guinea. Archaeol. Oceania 18:53-62.

Gorecki, P., M. Mabin, and J. Campbell. 1991. Archaeology and geomorphology of the Vanimo coast, Papua New Guinea: Preliminary results. Archaeol. Oceania 26:119-122.

Gosden, C. 1993. Understanding the settlement of the Pacific islands in the Pleistocene. Pages 131-136 in M. A. Smith, M. Spriggs, and B. Fankhauser, eds. Sahul in review: Pleistocene archaeology in Australia and Island Melanesia. Occasional Papers in Prehistory 24, Department of Prehistory, Research School of Pacific Studies, Australian National University, Canberra.

Gosden, C., and N. Robertson. 1991. Models for Matenkupkum: Interpreting a Late Pleistocene from southern New Ireland, Papua New Guinea. Pages 20-45 in J. Allen and C. Gosden, eds. Report of the Lapita Homeland Project. Department of Prehistory, Research School of Pacific Studies, Australian National University, Canberra.

Gosden, C., and J. Webb. 1994. The creation of a Papua New Guinean landscape: Archaeological and geomorphological evidence. J. Field Archaeol. 21:29-51.

Gosden, C., J. Webb, B. Marshall, and G. R. Summerhayes. 1994. Lolmo Cave: A midto late Holocene site, Arawe Islands, West New Britain Province, Papua New Guinea. Asian Perspect. 33:97-119.

Groube, L. 1971. Tonga, Lapita pottery and Polynesian origins. J. Polynesian Soc. 80:278-316.
1986. Waisted axes of Asia, Melanesia and Australia. Pages 168-177 in G. Ward, ed. Archaeology in ANZAAS Canberra. Canberra Archaeological Society, Canberra. 1989. The taming of the rain forests: A model for late Pleistocene forest exploitation in New Guinea. Pages 292-304 in D. R. Harris and G. C. Hillman, eds. Foraging and farming. Unwin Hyman, London.

Groube, L., J. Chappell, J. Muke, and D. Price. 1986. A 40,000 year old occupation site at Huon Peninsula, Papua New Guinea. Nature (Lond.) 324:453-455.

Hope, G. 1982. Pollen from archaeological sites. Pages 211-210 in P. Duerden and W. Ambrose, eds. Archaeometry: An Australasian perspective. Department of Prehistory, Research School of Pacific Studies, Australian National University, Canberra.

- In press. Environmental change and fire in the Owen Stanley Ranges, Papua New Guinea. Quat. Sci. Rev.

Hope, G. S., and J. Golson. 1995. Late Quaternary change in the mountains of New Guinea. Antiquity 265:818-830.

Hope, G., D. O'Dea, and W. Southern. 1999. Holocene vegetation histories in the western Pacific: Alternative records of human impact. Pages 388-404 in J.-C. Galipaud and I. Lilley, eds. The South Pacific, 5000 to 2000 B.P.: Colonisations and transformations. ORSTOM, Noumea.

Hope, G., and M. Spriggs. 1992. A preliminary pollen sequence from Aneityum Island, southern Vanuatu. Bull. Indo-Pac. Prehist. Assoc. 3:88-94.

Horrocks, M., and S. Bedford. 2005. Microfossil analysis of Lapita deposits in $\mathrm{Va}-$ nuatu reveals introduced Araceae (aroids). Archaeol. Oceania 39:67-74.

Kirch, P. V. 1997. The Lapita people. Blackwell, Oxford.

2001. Lapita and its transformations in Near Oceania: Archaeological investigations in the Mussau Islands, Papua New Guinea, 1985-1988. Contribution no. 59. Archaeological Research Facility, University of California at Berkeley, Berkeley. 
Kirch, P. V., T. L. Hunt, M. Weisler, V. Butler, and M. S. Allen. 1991. Mussau Islands prehistory: Results of the 1985-86 excavations. Pages 144-163 in J. Allen and C. Gosden, eds. Report of the Lapita Homeland Project. Occasional Papers in Prehistory 20, Department of Prehistory, Research School of Pacific Studies, Australian National University, Canberra.

Leavesley, M. 2004. Trees to the sky: Prehistoric hunting in New Ireland, Papua New Guinea. Ph.D. diss., Australian National University, Canberra.

. 2005. Prehistoric hunting strategies in New Ireland, Papua New Guinea: The evidence of the Cuscus (Phalanger orientalis) remains from Buang Merabak Cave. Asian Perspect. 44:218.

. 2007. A shark tooth ornament from Pleistocene Sahul. Antiquity 81:308-315.

Leavesley, M. G., M. I. Bird, L. K. Fifield, P. A. Hausladen, G. M. Santos, and M. L. di Tada. 2002. Buang Merabak: Early evidence for human occupation in the Bismarck Archipelago, Papua New Guinea. Aust. Archaeol. 54:55-57.

Leavesley, M., and J. Chappell. 2004. Buang Merabak: Additional early radiocarbon evidence of the colonisation of the Bismarck Archipelago, Papua New Guinea. Antiquity 78: No. 301.

Lentfer, C. J., and R. Green. 2004. Phytoliths and the evidence for banana cultivation at the Lapita Reber-Rakival site on Watom Island, Papua New Guinea. Rec. Aust. Mus. Suppl. 29:75-88.

Mountain, M.-J. 1991. Bulmer Phase I: Environmental change and human activity through the late Pleistocene into the Holocene in the highlands of New Guinea: A scenario. Pages 510-520 in A. Pawley, ed. Man and a half: Essays in Pacific anthropology and ethnobiology in honour of Ralph Bulmer. Polynesian Society, Auckland.

O'Connell, J. F., and J. Allen. 2007. PreLGM Sahul (Pleistocene Australia-New Guinea) and the archaeology of early modern humans. Pages 395-408 in P. Mellars, K. Boyle, O. Bar-Yosef, and C. Stringer, eds. Rethinking the human revo- lution: New behavioural and biological perspectives on the origin and dispersal of modern humans. McDonald Institute Monographs, Cambridge.

Pasveer, J. 2004. The Djief hunters: 26,000 years of rainforest exploitation on the Bird's Head of Papua, Indonesia. Mod. Quat. Res. Southeast Asia 17.

Pavlides, C. 1993. New archaeological research at Yombon, West New Britain, Papua New Guinea. Archaeol. Oceania 28:55-59.

- 1999. The story of Imlo: The organisation of flaked stone technologies into the lowland tropical rainforest of West New Britain, Papua New Guinea. Ph.D. thesis, La Trobe University, Melbourne. . 2004. From Misisil Cave to Eliva Hamlet: Rediscovering the Pleistocene in interior West New Britain. Pages 97-108 in V. Attenbrow and R. Fullagar, eds. A Pacific odyssey: Archaeology and anthropology in the western Pacific: Papers in honour of Jim Specht. Rec. Aust. Mus. Suppl. 29.

2006. Life before Lapita: New developments in Melanesia's long term history. Pages 205-227 in I. Lilley, ed. Archaeology of Oceania: Australia and the Pacific islands. Blackwell, Oxford.

Pavlides, C., and C. Gosden. 1994. 35,000 year old sites in the rainforests of west New Britain. Antiquity 68:604-610.

Pawley, A., and R. Green. 1973. Dating the dispersal of the Oceanic languages. Oceanic Ling. 12:1-67.

Poulsen, J. 1987. Early Tongan prehistory. Terra Australis 12. Department of Prehistory, Australian National University, Canberra.

Pritchard, I., and M. G. Leavesley. 2004. Buang Merabak shell analysis. Pages 271275 in M. Leavesley, Trees to the sky: Prehistoric hunting in New Ireland, Papua New Guinea. Ph.D. diss., Australian National University, Canberra.

Rosenfeld, A. 1997. Excavation at Buang Merabak, central New Ireland. Bull. IndoPac. Prehist. Assoc. 16:213-224.

Schmidt, L. 2004. Buang Merabak fish. Pages 237-239 in M. Leavesley, Trees to the sky: 
Prehistoric hunting in New Ireland, Papua New Guinea. Ph.D. diss., Australian National University, Canberra.

Spennemann, D. H. R. 1987. Availability of shellfish resources on prehistoric Tongatapu, Tonga: Effects of human predation and changing environment. Archaeol. Oceania 22:81-96.

Steadman, D. 1995. Prehistoric extinctions of Pacific island birds: Biodiversity meets zooarchaeology. Science (Washington, D.C.) 267:1123-1131.

- 1999. The Lapita extinction of $\mathrm{Pa}-$ cific island birds: Catastrophic versus attritional. Pages 375-386 in J.-C. Galipaud and I. Lilley, eds. The South Pacific, 5000 to 2000 B.P.: Colonisations and transformations. ORSTOM, Noumea.

- 2006. Extinction and biogeography of tropical Pacific birds. University of Chicago Press, Chicago.

Steadman, D., and P. Kirch. 1998. Biogeography and prehistoric exploitation of birds in the Mussau Islands, Bismarck Archipelago, Papua New Guinea. EMU 98:13-22.

Steadman, D. W., G. K. Pregill, and D. V. Burley. 2002. Rapid prehistoric extinction of iguanas and birds in Polynesia. Proc. Natl. Acad. Sci. U.S.A. 99:3673-3677.

Steadman, D. W., J. P. White, and J. Allen. 1999. Prehistoric birds from New Ireland, Papua New Guinea: Extinctions on a large Melanesian island. Proc. Natl. Acad. Sci. U.S.A. 96:2563-2568.

Stevenson, J., 2004. A late Holocene record of human impact from the southwest coast of New Caledonia. Holocene 14:888-898.

Storey, A. A., T. Ladefoged, and E. A. Matisoo-Smith. 2008. Counting your chickens: Density and distribution of chicken remains in archaeological sites of Oceania. Int. J. Osteoarchaeol. DOI: 10.1002/oa

Summerhayes, G. R. 2000. Recent archaeological investigations in the Bismarck Archipelago, Anir, New Ireland Province, Papua New Guinea. Bull. Indo-Pac. Prehist. Assoc. 19:167-174. 2007a. Island Melanesian pasts: A view from archaeology. Pages 10-35 in J. Friedlaender, ed. Genes, language and culture history in the Southwest Pacific. Oxford University Press, New York.

. 2007b. The rise and transformation of Lapita in the Bismarck Archipelago. Pages 129-172 in S. Chui and C. Sand, eds. From Southeast Asia to the Pacific: Archaeological perspectives on the Austronesian expansion and the Lapita Cultural Complex. Centre of Archaeological Studies, Academia Sinica, Taipei.

Summerhayes, G. R., and J. Allen. 1993. The transport of Mopir obsidian to Late Pleistocene New Ireland. Archaeol. Oceania 28:145-149.

Szabo, K., and G. Summerhayes. 2002. Worked shell artefacts: New data from Early Lapita. Pages 91-100 in S. Bedford, C. Sand, and D. Burley, eds., Fifty years in the field: Essays in honour and celebration of Richard Shutler's archaeological career. N. Z. Archaeol. Assoc. Monogr. 25.

Torrence, R., R. Neall, T. Doelman, E. Rhodes, C. McKee, H. Davies, R. Bonetti, A. Gugliemetti, A. Manzoni, M. Oddone, J. Parr, and C. Wallace. 2004. Pleistocene colonisation of the Bismarck Archipelago: New evidence from West New Britain. Archaeol. Oceania 39:101-130.

Veth, P., S. O'Connor, and M. Spriggs. 1998. After Wallace: Preliminary results of the first season's excavation of Liang Lemdubu, Aru Islands, Maluka. Pages 75-85 in M. J. Klokke and T. de Bruijn, eds. Proceedings of the 6th International Conference of the European Association of Southeast Asian Archaeologists, Leiden. Special Issue, Centre for South East Asian Studies, University of Hull, Hull.

White, J. P., K. A. W. Crook, and B. P. Ruxton. 1970. Kosipe: A Pleistocene site in the Papua highlands. Proc. Prehist. Soc. 36:152-170.

Wickler, S., and M. Spriggs. 1988. Pleistocene human occupation of the Solomon Islands, Melanesia. Antiquity 62:703-706. 
